\title{
A unique apudoma producing the glucagonoma and gastrinoma syndromes
}

\author{
J. DAWSON*† \\ D.M., M.R.C.P.
S. R. BLOOMł
M.A., D.Sc., M.D., F.R.C.P. \\ R. COCKEL* \\ M.A., M.B., F.R.C.P. \\ *Division of Medicine, Selly Oak Hospital, Raddlebarn Road, Birmingham B29 6JD and $\ddagger$ Department of
Medicine, Royal Postgraduate Medical School, Ducane Road, London W12 0HS
}

\begin{abstract}
Summary
A patient is described who presented with a 10 year history of intermittent peptic ulcer symptoms and a 3 year history of an undiagnosed skin rash. Investigations indicated raised plasma levels of gastrin, glucagon and pancreatic polypeptide. A single tumour was localised to the pancreas and resected. The tumour had the typical histology of an apudoma, and contained cells which stained for gastrin, glucagon, pancreatic polypeptide and neurotensin.
\end{abstract}

KEY WORDS: apudoma, gastrointestinal hormones, gastrin, glucagon, Zollinger-Ellison syndrome.

\section{Introduction}

It is becoming increasingly recognised that pancreatic endocrine tumours (apudomas) may contain more than one peptide hormone (Abe et al., 1979; Heitz et al., 1979). Nevertheless, individual patients whose tumours have not metastasised present with a single clinical syndrome due to over-production of one of the peptides. We report a patient who presented with the combined features of ZollingerEllison (gastrinoma) and glucagonoma syndromes in whom hypersecretion of 3 peptides was demonstrated.

\section{Case report}

A 70-year-old man was admitted to hospital in May 1980 with a 3 month history of constant upper abdominal pain with associated nausea, anorexia, weight loss $(10 \mathrm{~kg})$ and episodic diarrhoea. The symptoms had been partially relieved by cimetidine prescribed empirically. In 1971, he had been investigated for similar upper abdominal pain and a barium

† Present address: Department of Medicine, Queen Elizabeth Hospital, Birmingham. meal had suggested duodenal ulceration. Glycosuria had been noted on routine urinalysis in 1971. In 1977, he was admitted to a local skin hospital for investigation of a severe generalised erythematous rash with patchy bullous changes, particularly severe on the lower abdomen, thighs and buttocks. No firm diagnosis was made of this rash which was variously described as atypical bullous pemphigoid or infected discoid eczema. The rash eventually responded to oral tetracycline and fluorinated topical steroids. At the time of the current admission, the patient was cachectic, anaemic and had a patchy macular rash with areas of confluence on trunk and legs. Abdominal palpation revealed an ill-defined epigastric mass.

Blood tests showed a normocytic, normochromic anaemia (haemoglobin $9.1 \mathrm{~g} / \mathrm{dl}$ ), a raised erythrocyte sedimentation rate $(50 \mathrm{~mm} / \mathrm{hr})$, elevated blood glucose (10 mmol/litre) and alkaline phosphatase (106.5 u./litre) and a low serum albumin ( $25 \mathrm{~g} /$ litre).

Barium meal and upper gastrointestinal endoscopy showed an expanded duodenal loop with multiple peptic ulcers extending throughout the duodenum. Gastric secretion tests showed a raised basal acid concentration ( $83.8 \mathrm{mmol} /$ litre; normal less than 40$)$, but a normal basal acid output $(3.8 \mathrm{mmol} / \mathrm{hr}$; normal less than 5). Fasting plasma gastrointestinal hormones showed a raised gastrin $(306 \mathrm{pmol} / \mathrm{litre}$, normal less than $30 \mathrm{pmol} /$ litre), raised glucagon (475 pmol/litre, normal less than 50) and raised pancreatic polypeptide $(1850 \mathrm{pmol} /$ litre, normal less than 200) which failed to suppress with atropine (Bloom, Adrian and Polak, 1980). Somatostatin and vasoactive intestinal peptide levels were normal. Upper abdominal ultrasound, computed tomography and arteriography localised a single avascular tumour in the head of the pancreas. The ulcers failed to respond to high-dose cimetidine therapy and, despite continued therapy, his skin problems remained. He 
therefore underwent laparotomy and a single $9 \mathrm{~cm}$ diameter hypovascular tumour was removed from the head of the pancreas in a Whipple's procedure. Histological examination showed a typical endocrine tumour which, on immunocytochemistry, was shown to contain approximately equal proportions of 3 types of cells, staining for gastrin, glucagon, and pancreatic polypeptide respectively with, in addition, a few sparsely scattered neurotensin cells. Electron microscopy showed the presence of 4 cell types in the tumour. Radioimmunoassay of tumour extracts confirmed presence of gastrin (280 pmol/g wet weight) glucagon (119 $\mathrm{pmol} / \mathrm{g})$ and pancreatic polypeptide $(80 \mathrm{pmol} / \mathrm{g})$. Postoperative measurements of fasting plasma hormones showed that these had fallen to normal levels indicating origin from the single tumour. The patient, following an initial good recovery, died after recurrent surgery for persistent pancreatic anastomosis fistula problems 6 weeks after surgery.

\section{Discussion}

Pancreatic polypeptide production has been described previously in patients with pancreatic endocrine tumours associated with typical syndromes and does not, in itself, produce symptoms (Welbourn et al., 1981). However, although secretion of gastrin and glucagon has been reported in a patient who presented with an insulinoma (Broder and Carter, 1973), there have been no previous reports of the hypersecretion of gastrin, glucagon and pancreatic polypeptide and no reports of the co-existence of the clinical syndromes ascribed to hypergastrinaemia and hyper- $\frac{\varrho}{2}$ glucagonaemia in a single patient. This patient $\mathbb{\mathbb { D }}$ undoubtedly had features ascribed to over-pro- $\frac{C}{C}$ duction of both hormones for 9 years, having been noted to have glycosuria and a duodenal ulcer in $\stackrel{5}{\rightarrow}$ 1971 and severe clinical problems for 3 years before $\bar{c}$ diagnosis. The case emphasises the slow growth and 들 potential of endocrine pancreatic tumours to secrete $\frac{\bar{s}}{\partial}$ more than one hormone. It demonstrates the need for $\mathbb{\Phi}$ awareness of the presence of such tumours when patients manifest unusual combinations of symptoms, even when these symptoms are of long stand-. ing.

\section{Acknowledgments}

We thank Dr J. M. Polak for performing the histochemical studies, and Mrs Dawn Campbell for typing the manuscript.

\section{References}

ABe, K., Yamaguchi, K., Adachl, I. \& Yanaihara, N. (1979) Multiple hormone production in islet cell tumours. In: Proinsulin, Insulin and $C$-peptide (Eds. S. Baba, T. Kaneho and N. Yanihara), p. 374. Excerpta Medica, Amsterdam.

BloOM, S.R., AdRIAN, T.E. \& PolaK, J.M. (1980) Pancreatic polypeptide from pancreatic endocrine tumours. Lancet, ii, 1026.

Broder, L.E. \& CARTER, S.K. (1973) Pancreatic islet cell carcinoma. I. clinical features of 52 patients II. results of therapy with $\overrightarrow{0}$ streptomycin in 52 patients. Annals of Internal Medicine, 79, 19.

Heitz, P.U., Kasper, M., Polak, J.M. \& Kloppel, G. (1978 Pathology of the endocrine pancreas. Journal of Histochemis and Cytochemistry, 27, 1401.

Welbourn, R.B., Wood, S.M., PolaK, J.M. \& Bloom, S.R. (1981) Pancreatic endocrine tumours. In: Gut Hormones (Eds. S. R. Bloom and J. M. Polak), 2nd edn., p. 547. London, Churchill Livingstone, Edinburgh and London. 